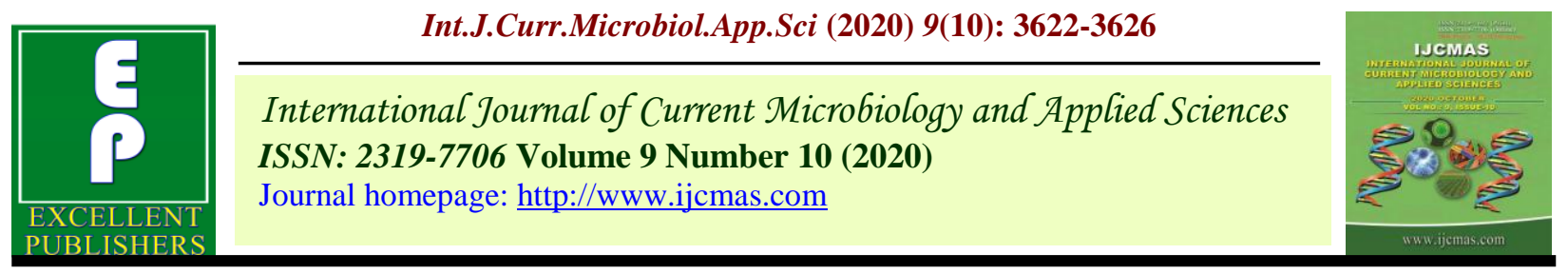

Original Research Article

https://doi.org/10.20546/ijcmas.2020.910.419

\title{
Physiological Modification of Patharchur Coleus forskohlii (Willd) Briq as Impact of Plant Growth Hormones
}

\author{
A. K. Choudhary ${ }^{1^{*}}$, S. D. Upadhyaya ${ }^{2}$ and A. Sharma ${ }^{3}$ \\ ${ }^{1}$ Department of Plant Pathology, RAK College of Agriculture, Sehore, Rajmata Vijayaraje \\ Scindia Krishi Vishwavidhyalya, Gwalior, Madhya Pradesh (MP), India \\ ${ }^{2}$ Department of plant physiology, JNKVV, Jabalpur (M.P.), India \\ ${ }^{3}$ Department of Biological Science, $R$ D University, Jabalpur (M.P.), India \\ *Corresponding author
}

\section{A B S T R A C T}

Keywords

Coleus, Cycocel, ppm, Patharchur, Hormones

Article Info

Accepted:

26 September 2020

Available Online:

10 October 2020
A field experiment was carried out in the farmer field adjoining, RAK College of Agriculture, Sehore (Madhya Pradesh) during 2015 and 2016 to find out Physiological modification of Patharchur Coleus forskohlii (Willd) Briq as impact of Plant Growth Hormones. Field experiment consisting of Plant Growth Hormones MH @ (100 and 150 ppm), Cycocel @(500 and 1000 ppm), NAA @(50 and 100 ppm), GA 3 @ (150 and 200 ppm) and water spray as control. Bjective of the study is to study the impact of plant growth Hormones on physiology of Coleus forskohlii (Willd) Briq. Physiological parameters like, Photosynthesis rate $\left(\mu \mathrm{mol} \mathrm{CO} \mathrm{Cm}^{-2} \mathrm{~s}^{-1}\right)$, Stomatal conductance (mmol $\left.{ }^{1} \mathrm{~m}^{2} \mathrm{~s}^{-1}\right)$, Transpiration rate $\left(\mathrm{mmol} \mathrm{H}_{2} \mathrm{O} \mathrm{m} \mathrm{m}^{-2}\right), \mathrm{CO}_{2}$ utilization $\left(\mu \mathrm{mol} \mathrm{CO}_{2} \mathrm{~mol}^{-1}\right)$ and $\mathrm{H}_{2} \mathrm{O}$ utilization (Kpa) by using IRGA and observations were recorded at 150 day after transplanting. Pooled data (2015 and 2016), 150 day after transplanting (DAT) revealed that application of Cycocel @ 1000 ppm resulted in increased Physiological parameters like, Photosynthesis rate $\left(\mu \mathrm{mol} \mathrm{CO}_{2} \mathrm{~m}^{-2} \mathrm{~s}^{-1}\right)$, Stomatal conductance $\left(\mathrm{mmol}^{-1} \mathrm{~m}^{2} \mathrm{~s}^{-1}\right)$, Transpiration rate $\left(m m o l \quad \mathrm{H}_{2} \mathrm{O} \mathrm{m} \mathrm{m}^{-2} \mathrm{~s}^{-1}\right), \mathrm{CO}_{2}$ utilization $\left(\mu \mathrm{mol} \mathrm{CO}_{2} \mathrm{~mol}^{-1}\right.$ ) and $\mathrm{H}_{2} \mathrm{O}$ utilization (Kpa), respectively $(13.14,14.56,3.64,13.53$ and 0.458$)$ followed by Cycocel @ 500 ppm $(12.68,13.64,3.19,13.38$ and 0.447$)$ as compare to control $(10.63,9.90,2.22$, 9.99 and 0.349$)$.

\section{Introduction}

Coleus forskohlii (Willd) Briq. [syn. C. barbatus (Andr.) Benth] is a plant in Indian origin (Valdes et al., 1987) belonging to mint family and grows in the subtropical temperate climates of India, Nepal, Thailand and Sri Lanka. Coleus is an aromatic perennial, with an erect stem and tuberus roots, reaching 30 to $60 \mathrm{~cm}$ tall having teardrop leaves (Prajapati et al., 2003). The tuberous root of coleus is rapidly spreading and typically golden brown (Thorne Research, 2006). Coleus has been used since ancient times in Hindu and Ayurvedic medicine. Coleus forskohlii (Willd) Briq. [syn. C. barbatus (Andr.) Benth] (Patharchur) is an exclusive source of a labdane diterpene forskolin along with 
diversified chemical contents. The crop has a great potential in future due to respected increase in demand for forskolin widely used in glaucoma, cardiac problem and also used in treatment of certain type of cancer (Shah et al., 1980). Plant growth regulators are group of naturally occurring, organic substances which effect growth processes at minute concentration, synthesized at one plant part and are capable of translocation to site of its action and regulating one or more physiological activity like Photosynthesis rate, Stomatal conductance, $\mathrm{Co}_{2}$ utilization (ppm) and $\mathrm{H}_{2} \mathrm{O}$ utilization.

\section{Materials and Methods}

This study was conducted at A field experiment was carried out farmer field adjoining RAK College of Agriculture, Sehore (Madhya Pradesh) during the year 2015 and 2016. The experiment will be conduct under Randomized Block Design (R.B.D.) with nine treatments in three replication. There were eight treatments $\mathrm{MH}$ (100 and $150 \mathrm{ppm}$ ), Cycocel (500 and 1000 ppm), NAA (50 and 100 ppm), GA3 (150 and $200 \mathrm{ppm}$ ) and the water being the control. The plant growth regulators were sprayed in three stages viz cutting stage, vegetative stages and reproductive stage. The $\mathrm{k} 8$ variety cutting were transplanted in main field. The whole plot was divided into 3 block each representing the replication. Each block was then divided into unit plot of $3 \times 3 \mathrm{~m}$ size. Well rooted cuttings were transplanted at $60 \mathrm{x}$ $30 \mathrm{~cm}$ spacing. The experiment plot fertilized with NPK $40 \mathrm{~kg}, 60 \mathrm{~kg}$ and $50 \mathrm{~kg} \mathrm{ha}^{-1}$ respectively. All the operations done regularly during growing season. Physiological parameters like, Photosynthesis rate $(\mu \mathrm{mol}$ $\left.\mathrm{CO}_{2} \mathrm{~m}^{-2} \mathrm{~s}^{-1}\right)$, Stomatal conductance $\left(\mathrm{mmol}^{-}\right.$ $\left.{ }^{1} \mathrm{~m}^{2} \mathrm{~s}^{-1}\right)$, Transpiration rate $\left(\mathrm{mmol} \mathrm{H}_{2} \mathrm{O} \mathrm{m}^{-2} \mathrm{~s}^{-1}\right)$, $\mathrm{CO}_{2}$ utilization ( $\mu \mathrm{mol} \mathrm{CO}_{2} \mathrm{~mol}^{-1}$ ) and $\mathrm{H}_{2} \mathrm{O}$ utilization (Kpa) by using IRGA and observations were recorded at 150 day after transplanting. The IRGA working on the principle of heteroatomic gas molecules absorb infera red radiation in specific infrared wavebands. Finally mean data of the all characters were computed for statistical analysis as per standard procedure given by (Panse and Sukhtme, 1989).

\section{Results and Discussion}

\section{Physiological observation}

The Impact of plant growth hormones on the physiological parameters of Coleus forskohlii like, Photosynthesis rate $\left(\mu \mathrm{mol} \mathrm{CO}_{2} \mathrm{~m}^{-2} \mathrm{~s}^{-1}\right)$, Stomatal conductance $\left(\mathrm{mmol}^{-1} \mathrm{~m}^{2} \mathrm{~s}^{-1}\right)$, Transpiration rate $\left(\mathrm{mmol} \mathrm{H}_{2} \mathrm{O} \mathrm{m} \mathrm{m}^{-2} \mathrm{~s}^{-1}\right), \mathrm{CO}_{2}$ utilization ( $\mu \mathrm{mol} \quad \mathrm{CO}_{2} \mathrm{~mol}^{-1}$ ) and $\mathrm{H}_{2} \mathrm{O}$ utilization (Kpa) were judged at 150 DAT of crop. It was observed that all the physiological parameters of crop were noticed to be significantly influenced at by all treatments at $150 \mathrm{DAT}$.

\section{Photosynthesis rate $\left(\mu \mathrm{mol} \mathrm{CO}_{2} \mathrm{~m}^{-2} \mathrm{~s}^{-1}\right.$ )}

Pooled data at 150 DAT was observed to be in the range $13.14-10.19$ as compared to control. The highest Photosynthesis rate 13.14 was recorded treatment with Cycocel (CCC) 1000 as compared to lowest Photosynthesis rate 10.19 . NAA $50 \mathrm{ppm}$. Photosynthesis rate 3524.23 was found in control as compared to other treatment.

\section{Stomatal conductance $\left(\mathrm{mmol}^{-1} \mathrm{~m}^{2} \mathrm{~s}^{-1}\right)$}

Pooled data 150DAT was observed to be in the range $14.56-11.40$ as compared to control. The highest Stomatal conductance 14.56 was recorded treatment with Cycocel (CCC) 1000 as compared to lowest Stomatal conductance 11.40 NAA $50 \mathrm{ppm}$. Stomatal conductance 9.90 was found in control as compared to other treatment (Table 1 and Fig. $1)$. 
Table.1 Impact of growth hormones on physiological parameters of Patharchur Coleus forskohlii (Willd) Briq

\begin{tabular}{|c|c|c|c|c|c|c|c|c|c|c|c|c|c|c|c|}
\hline \multirow[t]{2}{*}{ Treatments } & \multicolumn{3}{|c|}{$\begin{array}{l}\text { Photosynthesis rate } \\
\left(\mu \mathrm{mol} \mathrm{CO}_{2} \mathrm{~m}^{-2} \mathrm{~s}^{-1}\right)\end{array}$} & \multicolumn{3}{|c|}{$\begin{array}{l}\text { Stomatal conductance } \\
\left(\mathrm{mmol}^{-1} \mathrm{~m}^{2} \mathrm{~s}^{-1}\right)\end{array}$} & \multicolumn{3}{|c|}{$\begin{array}{l}\text { Transpiration rate } \\
\left(\mathrm{mmol} \mathrm{H}_{2} \mathrm{O} \mathrm{m}^{-2} \mathrm{~s}^{-1}\right)\end{array}$} & \multicolumn{3}{|c|}{$\begin{array}{c}\mathrm{CO}_{2} \text { utilization } \\
\left(\mu \mathrm{mol} \mathrm{CO}_{2} \mathrm{~mol}^{-1}\right)\end{array}$} & \multicolumn{3}{|c|}{$\begin{array}{l}\mathrm{H}_{2} \mathrm{O} \text { utilization } \\
\text { (Kpa) }\end{array}$} \\
\hline & 2015 & 2016 & Pooled & 2015 & 2016 & Pooled & 2015 & 2016 & Pooled & 2015 & 2016 & Pooled & 2015 & 2016 & Pooled \\
\hline MH @100 ppm & 12.07 & 11.78 & 11.92 & 13.69 & 13.28 & 13.48 & 2.84 & 2.73 & 2.79 & 12.99 & 12.37 & 12.68 & 0.427 & 0.399 & 0.413 \\
\hline MH @150 ppm & 12.53 & 12.03 & 12.28 & 13.78 & 13.36 & 13.57 & 3.13 & 3.06 & 3.10 & 13.10 & 12.36 & 12.73 & 0.456 & 0.437 & 0.446 \\
\hline CCC@500 ppm & 12.77 & 12.60 & 12.68 & 13.91 & 13.37 & 13.64 & 3.29 & 3.09 & 3.19 & 3.70 & 13.05 & 13.38 & 0.453 & 0.440 & 0.447 \\
\hline CCC@1000 ppm & 13.27 & 13.02 & 13.14 & 14.73 & 14.39 & 14.56 & 3.76 & 3.52 & 3.64 & 13.96 & 13.10 & 13.53 & 0.468 & 0.449 & 0.458 \\
\hline NAA@50 ppm & 10.28 & 10.10 & 10.19 & 11.50 & 11.29 & 11.40 & 2.32 & 2.21 & 2.26 & 10.92 & 10.37 & 10.64 & 0.380 & 0.369 & 0.374 \\
\hline NAA @100 ppm & 11.24 & 10.72 & 10.98 & 12.05 & 11.64 & 11.85 & 2.47 & 2.27 & 2.37 & 12.41 & 11.64 & 12.03 & 0.379 & 0.347 & 0.363 \\
\hline GA3 @150 ppm & 11.53 & 11.35 & 11.44 & 12.41 & 11.83 & 12.12 & 2.51 & 2.23 & 2.37 & 12.82 & 11.91 & 12.36 & 0.398 & 0.386 & 0.392 \\
\hline $\mathrm{GA}_{3} @ 200$ ppm & 11.94 & 11.42 & 11.68 & 12.36 & 11.95 & 12.16 & 2.59 & 2.30 & 2.44 & 12.97 & 11.91 & 12.44 & 0.422 & 0.396 & 0.409 \\
\hline CONTROL & 10.78 & 10.47 & 10.63 & 10.15 & 9.66 & 9.90 & 2.31 & 2.12 & 2.22 & 10.24 & 9.73 & 9.99 & 0.357 & 0.341 & 0.349 \\
\hline Mean & 5.20 & 14.78 & 14.99 & 16.37 & 15.82 & 16.10 & 3.60 & 3.36 & 3.48 & 16.16 & 15.20 & 15.68 & 0.534 & 0.509 & 0.522 \\
\hline $\mathrm{SEm} \pm$ & 0.53 & 0.51 & 0.52 & 0.77 & 0.81 & 0.79 & 0.21 & 0.22 & 0.21 & 0.54 & 0.49 & 0.51 & 0.020 & 0.022 & 0.021 \\
\hline $\mathrm{CD}$ at $5 \%$ & 1.59 & 1.54 & 1.56 & 2.31 & 2.43 & 2.37 & 0.63 & 0.66 & 0.64 & 1.62 & 1.46 & 1.54 & 0.061 & 0.064 & 0.063 \\
\hline
\end{tabular}


Fig.1 Impact of growth hormones on physiological parameters of Patharchur Coleus forskohlii (Willd) Briq
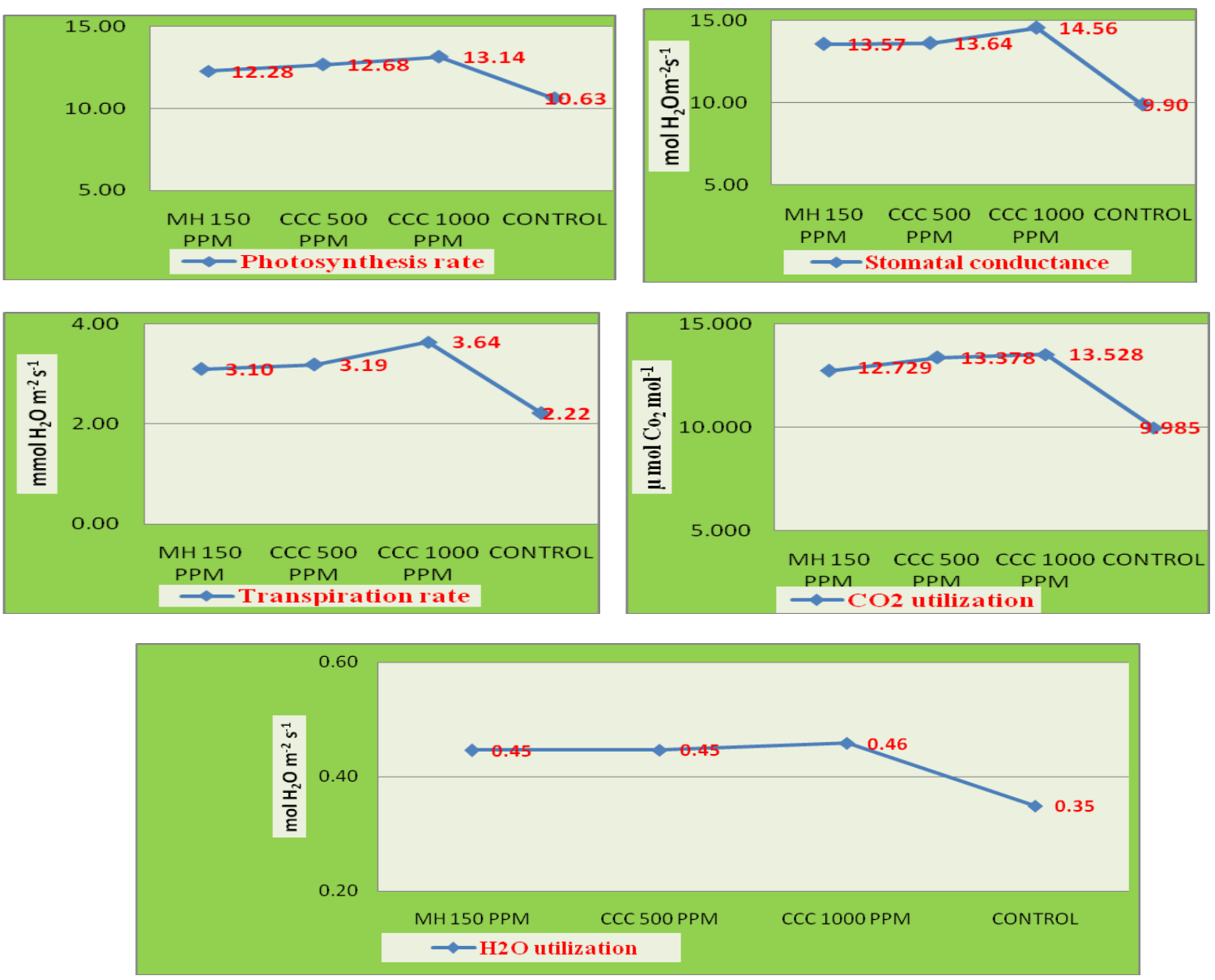

\section{Transpiration rate $\left(\mathrm{mmol} \mathrm{H}_{2} \mathrm{O} \mathrm{m}^{-2} \mathrm{~s}^{-1}\right)$}

Pooled data 150DAT was observed to be in the range 3.64-2.26 as compared to control. The highest Transpiratiorn rate 3.64 was recorded treatment with Cycocel (CCC) 1000 as compared to lowest Transpiratiorn rate 2.26 NAA $100 \mathrm{ppm}$. Transpiratiorn rate 2.22 was found in control as compared to other treatment.

\section{$\mathrm{CO} 2$ utilization $\left(\mu \mathrm{mol} \mathrm{CO}_{2} \mathrm{~mol}^{-1}\right)$}

Pooled data 150DAT was observed to be in the range 13.53 - 10.64 as compared to control. The highest $\mathrm{CO}_{2}$ utilization 13.53 was recorded treatment with Cycocel (CCC) 1000 as compared to lowest $\mathrm{CO}_{2}$ utilization 10.64 NAA 50 ppm. $\mathrm{CO}_{2}$ utilization 9.99 was found in control as compared to other treatment.

\section{$\mathrm{H}_{2} \mathrm{O}$ utilization (Kpa)}

Pooled data 150DAT was observed to be in the range $0.46-0.37$ as compared to control. The highest $\mathrm{H}_{2} \mathrm{O}$ utilization 0.46 was recorded treatment with Cycocel (CCC) 1000 as compared to lowest $\mathrm{H}_{2} \mathrm{O}$ utilization 0.37 NAA 100 ppm. $\mathrm{H}_{2} \mathrm{O}$ utilization 0.35 was found in control as compared to other treatment. 
The studies on physiological parameters, pooled data (2015 and 2016), 150 day after transplanting (DAT) revealed that application of Cycocel @1000 ppm resulted in increased Physiological parameters like, Photosynthesis rate $\left(\mu \mathrm{mol} \mathrm{CO} \mathrm{C}^{-2} \mathrm{~s}^{-1}\right)$, Stomatal conductance $\left(\mathrm{mmol}^{-1} \mathrm{~m}^{2} \mathrm{~s}^{-1}\right)$, Transpiration rate $\left(\mathrm{mmol} \mathrm{H}_{2} \mathrm{O}\right.$ $\left.\mathrm{m}^{-2} \mathrm{~s}^{-1}\right), \mathrm{CO}_{2}$ utilization $\left(\mu \mathrm{mol} \mathrm{CO} \mathrm{Col}^{-1}\right)$ and $\mathrm{H}_{2} \mathrm{O}$ utilization (Kpa) respectively (13.14, 14.56, 3.64, 13.53 and 0.458) followed by Cycocel @ 500 ppm (12.68, 13.64, 3.19, 13.38 and 0.447) as compare to control $(10.63,9.90,2.22,9.99$ and 0.349$)$.

\section{Acknowledgments}

We are thankful to the Department of Plant Physiology, College of Agriculture, Jabalpur (JNKVV), Department of Biological Science, RDVV, Jabalpur for providing lab facilities for the analysis. and with thanks for the farmer for conducted of experiment

\section{References}

Panse, V.G. and Sukhatme, P.V. (1989). Statical methods for Agriculture workers. ICAR New Delhi, pp. 97105.

Prajapati ND, Purohit SS, Sharma AK, Kumar T (2003). A Handbook of Medicinal Plants, Agrobios Publishers, India, P. 162.

Shah, V., Bhat, S. V. Bajwa, B. S., Domacur, H. and De souza, N. J. (1980). The occurrence of forskolin in Labiatae. Plant Med., 39: 183-185

Thorne Research (2006). Monograph on Coleus forskohlii. Alternat. Med. Rev. 11(1):47-51.

Valdes, L. J., Mislankar, S. G. and Paul, A. G. (1987). Colius barbatus (Lamiaceae) and the potential new drug forskolin (Colenol). Eco. Bot., 41: 474-483.

\section{How to cite this article:}

Choudhary, A. K., S. D. Upadhyaya and Sharma, A. 2020. Physiological Modification of Patharchur Coleus forskohlii (Willd) Briq as Impact of Plant Growth Hormones. Int.J.Curr.Microbiol.App.Sci. 9(10): 3622-3626. doi: https://doi.org/10.20546/ijcmas.2020.910.419 